\title{
THINK OF THE CONSEQUENCES ${ }^{1}$
}

\author{
BY LINCOLN R. THIESMEYER ${ }^{2}$
}

The title under which I am making these Luncheon remarks is both an exhortation and a challenge. It is one I have had to use frequently with my second son, especially during his teen-age years. He is impulsive, more than most, I think - a trait which, I am sure, he has inherited strictly from his mother's side of the family. Frequently over the years he has gotten into scrapes of various kinds because he acted without careful forethought of the consequences. As he matured, however, he began to think things through ahead of time. On one occasion, for example, a battery of high school tests had shown that he had interest in and aptitude for three things-science, social science and music. When we asked what he intended to do about it, his reply was: "All the way home from school I was puzzling over how I could capitalize on all three of those abilities at once. Dad, you know, I think I have it figured out. I'm going to become a singing psychiatrist!" Actually, he did go into social service work for a while, dealing with juvenile delinquents, probably because he had been so close to becoming one himself that he could understand them and speak their language. Perhaps it is but poetic justice that today he is an attorney whose effectiveness may largely depend on his ability to warn others of the consequences of what they propose to do, or deal with the tribulations they suffer as a result of their actions.

As an individual matures, he learns to concern himself not only with his own decisions and behaviour but also with the outcome of the actions of others and with the interplay of factors in the physical, economic, sociological and political environment. Hence, a major part of an adult's conscious thinking time must be concerned with consequences-in analysis of those which exist and in anticipation of those which may eventuate. Organized labour is concerned over the effects of the inexorable trends to mechanization and to computer operations of production plants. Certain major powers seem to see untold benefits from being the first to put a citizen on the moon. Some citizens of at least one of these are led to wonder whether similar effort and fabulous expenditure of funds devoted to such things as education, medical research, better world distribution of food and the war on poverty would not be yielding even greater and more immediate benefits to society. And, all over Canada, as we face its Centennial Year, people are wondering what moves Quebec will make and what countermoves would be appropriate to ensure the continuance of a single, increasingly-respected and ever stronger Nation.

In all such matters and in the special concerns over consequences which we in science and technology, in forestry and in the forest products industries must have-about which I shall be speaking in a moment-there is necessarily

\footnotetext{
${ }^{1}$ Paper delivered at the Annual Meeting of the Canadian Institute of Forestry, Banff, Alberta, October, 1966

${ }^{2}$ President, Pulp and Paper Research Institute of Canada, Pointe Claire, Quebec.
} 
considerable speculation. This is not all bad. One of my beloved professors said that the cure for bad speculation is more speculation. (A wag on the staff of the campus newspaper misquoted him as saying that the cure for bad speculation is more bad speculation!) Situations are so complex, there are so many variables and so many unknowns and things move so quickly that it could hardly be otherwise. Some say that the wizardry of the computer specialist will remove some of the need for speculation. But, until that happy day, we must depend on that best of all possible computers-the blob of gray matter inside each human head.

Scientists are generally dissatisfied with the status quo. Some of them are unhappy because they want to know more about why and how things work. A few of them insist on doing such things as counting and measuring the length of the hairs on the left anterior legs of a spider before concluding that it can walk. Those who focus on applied research and technology are eager to see changes because they have anticipated the beneficial results of such changes. Similarly, some foresters are content with the measurement, analysis and distribution of our fibre resources. Others in research or in forest management must concern themselves with the future outcome of actions taken today.

The effects of the combination of a benign climate, abundant rain-fall and dense stands of large trees are now being seen in the awesome growth of the pulp and paper industry in British Columbia. Those who said in 1950 that by 1975 the centre of pulp and paper production in Canada might well be in that Province may not be missing the mark by far. Already, it is apparent that nearly half of the pulp production will be there by the early 1970 s.

The current expansion in pulp and paper production not only in British Columbia but also in the rest of Canada is likewise a reflection of the fact that Europe has been running out of wood, Scandinavia will not be far behind (although extensive aerial fertilization of forests in these northern countries may stave off the evil day for a while), and Japan, now the third country in pulp and paper production, does not have enough fibre to feed its machines. This round of expansion is being financed in a major way by capital from continental Europe, Scandinavia, the United Kingdom, the U.S. and Japan. At the same time, Canadian and U.S. companies are establishing or acquiring converting and manufacturing facilities in many countries. All of this is making the industry truly international in character.

What are the implications of these developments in terms of international trade? Does the existence of so many industrial marriages mean that the industry is joining for common action against its competitors in other industries? What about the exchange of scientific and technological information-will this be freer than ever before? Many Canadians say they are happy to have so much foreign capital coming into the country to help develop its resources, to pay its wages and its taxes, to bring skilled technicians into the country and to set the precedent for having others of its resource-based industries become similarly international in character and financing. Will we hear echoes in the not-too-distant future of the complaint that too much of Canadian industry is dominated by foreign interests or that the equity shares of too many companies have such high non-Canadian ownership that some forms of 
punitive or restrictive action should be taken? Will these foreign interests help us to become even bigger hewers of wood and larger users of water, or will they help to stimulate secondary industry in this country? What steps, if any, must we take to ensure that wood supplies will be adequate to foster a continuation of such internationally-based development of the forest products industries into the beginning of the next century?

It is interesting to note that while the expansion has been largely toward the west in Canada, it has been in the opposite direction in the USSR. In Siberia five new mills are already under construction, one of them an integrated complex which will annually produce $1,000,000$ tons of products, about $20 \%$ more than any mill existing in the world today. Between 1970 and 1972 the Russians will build seven more mills in Siberia and between 1972 and 1980 they have plans for 18 more. This will represent 30 mills in 15 years in Siberia, while elsewhere in the U.S.S.R. will be additional new mill complexes, some of them also producing a million tons a year. The Russians are even beginning to worry about the possible pollution of Lake Baikal. If their plans materialize it will mean the consumption in Siberia of about 40 million cords of wood per year. The Russians have announced that they intend to catch up with Canada and plan to become an important factor in export markets. What will be the impact on us if they succeed in these ambitions?

Meanwhile, it seems ironical that China, where paper was probably invented, has a serious shortage of fibre resources. With the growing literacy of its hundreds of millions and the improvement of their living standards, however gradual, it is apparent that China must become a major importer of pulp, paper and paperboard products for many years ahead. In the present political climate, of her own making, it seems unlikely that she will turn either to Russia or to the United States. Perhaps, this underlies what would appear to be some of her ambitions with regard to her South and Southwest. We read that there is "a patent dearth of all kinds of forest products in China and this has undoubtedly had far-reaching effects on almost every aspect of her economy." Hence, it could be argued that forestry is of greater importance in China today than it is in any other country of the world. Agricultural productivity depends on water conservation and, therefore, on afforestation. Moreover, the general importance of timber resources for the development of railroads and industrial construction is well known. Will Canada, which appears to have no qualms about sharing its surplus wheat with China, also have surplus wood to share with her in the years ahead?

With the forest products industry of Canada becoming so much more international in its scope, what changes should be made in the training of young foresters in this country and what are the job opportunities here and elsewhere in the world which they will find open to them? You will note that I have not even mentioned the forestry problems and opportunities in the tropical areas and in the underdeveloped nations which are everywhere yearning for self-sufficiency in forest products. Apart from the meaning of bilingualism to Canada, what new emphasis should be given to education in foreign languages in forestry schools? Will the vice-president/woodlands of a big internationally-based company have to have experience in the management of vastly different types of forests in the several countries where the company functions? 
Our Pulp and Paper Institute has been a leading advocate of full-tree logging because of its implications of reducing logging costs and increasing utilization of the raw material. But we, ourselves, are beginning to accumulate evidence that, on certain sites at least, this may be the wrong thing to do from the standpoint of nutrient removal. In the black spruce swamps of Canada's boreal forests, for example, where the root systems are shallow and the trees are nourished primarily from chemicals released in the thick bumus layer, removal of the entire tree would lead inevitably to depletion of the chemicals available from the natural recycling of nutrients between that layer and the crown. Yet, despite the warning provided by such evidence, some woodlands managers are disposed to believe that full-tree logging of such sites may yet prove to be economic, even if subsequent fertilization of these sites is necessary to restore a tree crop.

Apart from the devastating effects of fire and of insect attack and diseases, the most spectacular thing in Canadian woodlands during the past quartercentury has been the increasing drive toward mechanization of logging and other woodlands operations. This has proceeded with little thought to the aftermath. Hence, we are currently studying the silvicultural implications of mechanization. One might say that research on this should have preceded the widespread use of machines. But, how could this have been done until the bewildering array of equipment was actually in use on diverse forest sites? I believe that the research will not point so much to the use of other machines or to better practices in operating them, but rather to remedial measures to compensate for the damage being done. The important point is that the industry is alert to the possibility of damage and is conducting studies to find out the consequences of its actions and what can be done about them.

In one of the companies which helped to make possible our studies of hydraulic chip transport in pipelines, there was a first-class example of seeing some of the implications, should that company install such a pipeline. The mill people began to wonder what effects a supply of thoroughly saturated chips coming to the mill under pressure would be on the cooking conditions and on the recovery system. Moreover, they began to think about the nature of the water in which the wood would be transported. It was known to have a high content of fine silt and would need to be treated, either at the woodlands end of the pipeline or at the mill, before it could be used by the mill The cost of such treatment loomed large. Therefore, they began thinking of other alternatives. They speculated on what would happen if, instead, black liquor were to be pumped from the mill to the head of the pipeline and the chips transported in it. What would be the economics? What effect would this have on the suitability of the chips for subsequent pulping? Even if that company decides never to have a chip pipeline, I venture to say that the stimulation to its personnel both in the woodlands department and at the mill to stretch their minds away from thinking about conventional practices will prove to have been a good investment of that company's share of the costs in the project.

One of the biggest problems which a woodlands manager of our industry faces today is labour-not just the spiralling rise of wages and fringe benefits but the increased skills required to operate efficiently and maintain the mechanical equipment and the improved living conditions which such labour 
is demanding. Complex and costly machinery cannot be left to a constant turnover of operators. This means that the day of the part-time woods worker is rapidly disappearing and a stable labour force is emerging. Such people do not like to work away from home. Even the young unmarried ones prefer to be close to female companionship, to the discotheque and to the TV (or boob-tube). Those whose jobs require that they work out of distant camps demand conveniences and comforts which are very costly to provide at such remote locations. Companies dislike to get into the business of owning and operating communities. Therefore, in some places, the companies are providing transportation for their woods workers from stable communities to the operating sites. There is even talk of using helicopter busses where distances are greater and ground transportation would take too long.

This combination of circumstances puts a premium on the wood closest to the mill. New plantations at such sites will not be ready for harvesting in time to meet this situation. Hence, one must think of doing everything possible to increase the growth at such locations and on the better sites of a company's operating limits, whether they be only a few miles from the mill or many scores of miles away and connected to it by a road system or a pipeline. The economic implications of this are too obvious to require elaboration. And one begins to wonder whether the abundant wood which we know exists in what are now regarded as inaccessible forests will ever become accessible economically.

Given these conditions, I respectfully suggest that company foresters among you have a dazzling opportunity and a high responsibility to make the case to your managements for intensive forestry across Canada in our time. And I would further suggest that foresters generally should play a larger and stronger part than they have in persuading governments to encourage such practice. The rationale is there and it can be translated into the cold, hard facts of economics which, after all, are one good basis for government policy.

In these brief remarks, I have tossed out many questions and I don't propose to even suggest the answers to them. But, in the job I have, I cannot refrain from one final query - What would happen if the funds for research in forestry available to departments of government, to forestry schools, to the research departments of individual companies and to a research institute such as ours were to be quadrupled in the next few years? Ah, me... just think of the consequences! 